\title{
Detection of antimicrobial drug residues in edible tissues from Bunaji cattle slaughtered in Minna modern abattoir
}

Adama, J. Y., Mande, L. L. and Usman, A.

Department of Animal Production, School of Agriculture and Agricultural Technology, Federal University of Technology, P.M.B 65, Minna, Niger State Nigeria

Correspondence author: adama_live@yahoo.com:+234 08057058455

\begin{abstract}
The occurrence of antimicrobial drug residues in edible tissues of slaughtered animals in Nigeria due to indiscriminate drug administration by livestock farmers necessitated this study in Bunaji cattle slaughtered in Minna modern abattoir. A total of 168 edible tissues comprising of meat, liver and kidney were collected from 56 Bunaji cattle slaughtered every two weeks for a period of four months. Microbial inhibition test was employed to screen samples for evidence of antimicrobial drug residues as well as quantitative test using ELISA test kid. 29 (51.78\%) samples tested positive with zone of inhibition at various levels of residue (12, 13, 15, 17, 19 and 20mm), which signified high levels of residue. Samples from female cattle contained highest residue value of 20 (68.90\%) and values at $20 \mathrm{~mm}$. Ages between 6-10 years had 17 (58.62\%) while the lowest residue was recorded at older animals above 10 years $5(17.24 \%)$. The quantitative test using ELISA test kid showed a total of 89 $(52.78 \%)$ of the samples confirmed positive at various inhibition levels. Oxytetracycline residues from the positive results were determined for meat, liver and kidney. The results obtained indicated that, $100 \%$ of the samples contained oxytetracycline residues at various optical density levels. $41.78 \%$, were above set residue limits of $0.2 \mathrm{mg} / \mathrm{kg}, 0.6 \mathrm{mg} / \mathrm{kg}$ and 1.2 $\mathrm{mg} / \mathrm{kg}$ for meat, liver and kidney, respectively. From the results it is authenticated that consumers in Minna metropolitan are predisposed to health hazards due to high levels of antimicrobials residues in meat slaughtered in the abattoir. This emphasises the need for effective prevention of infectious diseases, enforcement of ante-mortem inspection, general enlightenment and possible establishment of antimicrobial residues monitoring unit in the studyarea.
\end{abstract}

Keywords: Antimicrobial, drug residues, meat, liver, kidney, Bunaji cattle

La Détection de résidus d'antimicrobiens dans les tissus consommables de bovins

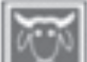
Bunaji abattus dans l'abattoir moderne de Minna

\section{Résumé}

La présence de résidus de médicaments antimicrobiens dans les tissus consommables d'animaux abattus au Nigéria en raison de l'administration de médicaments sans discernement par les éleveurs a nécessité cette étude sur des bovins Bunaji abattus dans l'abattoir moderne de Minna. Un total de 168 tissus consommables comprenant de la viande, du foie et des reins ont été prélevés sur 56 bovins Bunaji abattus toutes les deux semaines pendant une période de quatre mois. Microbial inhibition test was employed to screen samples for evidence of antimicrobial drug residues as well as quantitative test using ELISA test kid. 29(51.78\%) samples tested positive with zone of inhibition at various levels of residue $(12,13,15,17,19$ and $20 \mathrm{~mm})$, which signified high levels of residue.29 échantillons $(51,78 \%)$ ont été testés positifs avec une zone d'inhibition à divers niveaux de résidus $(12,13$, $15,17,19$ et $20 \mathrm{~mm}$ ), ce qui signifie des niveaux élevés de résidus. Les échantillons de bovins femelles contenaient la valeur de résidu la plus élevée de $20(68,90 \%)$ et les valeurs à $20 \mathrm{~mm}$. Les âges entre 6 et 10 ans en comptaient 17 (58,62\%) tandis que le résidu le plus bas était enregistré chez les animaux plus âgés de plus de 10 ans 5 (17,24\%). Le test quantitatif 


\section{Detection of antimicrobial drug residues in edible tissues from Bunaji cattle}

utilisant le test 'ELISA kid' a montré un total de 89 (52,78\%) des échantillons qui se sont confirmés positifs à divers niveaux d'inhibition. Les résidus d'oxytétracycline des résultats positifs ont été déterminés pour la viande, le foie et les reins. Les résultats obtenus ont indiqué que $100 \%$ des échantillons contenaient des résidus d'oxytétracycline à divers niveaux de densité optique. 41,78\%, étaient au-dessus des limites de résidus fixées de 0,2 mg $/ \mathrm{kg}, 0,6 \mathrm{mg} / \mathrm{kg}$ et 1,2 mg / kg pour la viande, le foie et les reins, respectivement. À partir des résultats, il est authentifié que les consommateurs de la métropole de Minna sont prédisposés à des risques pour la santé en raison des niveaux élevés de résidus d'antimicrobiens dans la viande abattue dans l'abattoir. Cela souligne la nécessité d'une prévention efficace des maladies infectieuses, de l'application de l'inspection ante mortem, de la prise de conscience générale et de la création éventuelle d'une unité de surveillance des résidus d'antimicrobiens dans la zone d'étude.

\section{Mots clés : antimicrobien, résidus de médicaments, viande, foie, rein, bovins Bunaji}

\section{Introduction}

The Drug administration to domestic animals requires not only consideration of its effect on the animals but also the effect on humans who consume the product from such animals. Antibiotics are natural product of microorganisms or identical synthetic products or similar semisynthetic products that inhibit the growth of or destroy microorganisms (Karbis, 2007). In animal health practice, antibiotics are widely used as therapeutic prophylactic or as growth promoting agents (Donoghue, 2003). Antibiotics are of different types, with various pharmacokinetic activities which are often neglected during slaughter, and hence become potential hazard to humans. The presence of antibiotics in meat and other food of animal origin is one of the most important indices for their safety to human consumers (Kozanova et al., 2001). Many livestock farmers administer antibiotics indiscriminately for purposes of treating or preventing an ailment or as growth promoters without consulting experts for necessary advice, such animals are often slaughtered without recourse to the withdrawal period. The Indiscriminate use of antibiotics in livestock has raised serious public health concerns globally, especially in sub-Sahara Africa and particularly Nigeria (Shehu, 2018). Drug residue arises when treated animals are slaughtered without recourse to pharmacokinetics of the specific drug administered, this situation usually occurs with prolonged administration and over dosage of antimicrobial agent, especially if these animals are slaughtered immediately (vinedresser, 1989) as cited by (Gabriel et al., 2012). Toxic level of antimicrobial residues in food animals are known to cause divers health hazards to susceptible unsuspecting human consumers (Gabriel et al., 2012).

\section{Materials and methods \\ Experimental site}

The samples were collected from Minna Modern abattoir located along Tayi village in Minna Niger state, Nigeria. Minna is situated on a latitude 93105 and longitude 7 421 north, with annual rainfall of 1,200$1,300 \mathrm{~mm}$ and mean temperature of $21-36 \mathrm{c}$, the area has an altitude of $1,46 \mathrm{~m}$ above sea level in the southern-guinea savannah vegetation zone of Nigeria. It is characterised by two seasons, the wet season (April - October and dry season November -March) (NSFCO, Minna, 2015).

Sample collection, duration and preservation

One hundred and sixty-eight (168) samples from 3 edible parts of cattle (liver, Muscles and kidney) weighing $50 \mathrm{~g}$ each were 
randomly collected from slaughtered Bunaji cattle in Minna modern abattoir for a period of 4 months at 2 week intervals, with special emphasis on age, sex and time intervals. The samples were properly packed and labelled in a poly bag and store under a refrigerator at a temperature of $20^{\circ} \mathrm{C}$ until the time for the analysis.

\section{Location of the analysis}

The analysis was carried out in the Department of Veterinary Public Health and preventive medicine, Faculty of veterinary medicine, Ahmadu Bello University Zaria, Nigeria.

\section{Sample analysis}

The following laboratory techniques were used for sample analysis:

Microbial inhibition test and Elisa kit test (confirmatory)

\section{Laboratory procedure}

An adapted microbial inhibition test was employed to screen samples for evidence of antimicrobial drug residues as described by Huber et al. (1969). Thereafter, based on the positive results obtained from the screening test, quantitative measurement of Oxytetracycline residues was done using Oxytetracycline ELISA test kits which was purchased from BIOTUVA Life sciences, 4283 Express Lane, suite 728504 Sanasota, FL 34249 .

Table 1: Screening of antimicrobials residues obtained from the tissue samples of Bunaji cattle slaughtered in the study area

\begin{tabular}{llll}
\hline SAMPLE & POSITIVE (\%) & NEGATIVE (\%) & TOTAL \\
\hline MEAT & $29(51.79)$ & $27(48.21)$ & 56 \\
LIVER & $37(66.07)$ & $19(32.92)$ & 56 \\
KIDNEY & $23(41.07)$ & $33(56.92)$ & 56 \\
TOTAL & $\mathbf{8 9 ( 5 2 . 9 7 )}$ & $\mathbf{7 9 ( 4 7 . 0 3 )}$ & $\mathbf{1 6 8}$ \\
\hline
\end{tabular}

Distribution of antimicrobial residues from the positive samples based on sex and age

The results for distribution of Antimicrobial residues from the positive samples based on sex and age is shown in Table 2 . The result on sex variation shows that $26(29.2 \%)$ of the total positive samples were males with $9(31.03 \%), 8(25.80 \%)$ and $9(39.13 \%)$

\section{Statistics analysis}

The data obtained were expressed in percentages and presented as tables for both antimicrobial screening and Oxytetracycline residues. Statistical package for social sciences (IBM USA Version 16.0 2010) was used to analyse the data.

\section{Results}

A total of 168 samples of meat (Beef), liver and kidney samples from 56 Bunaji cattle of different sex and age were screened for antimicrobial drug residues through growth inhibition method using nutrient Agar seeded with Bacillus subtilis. The positive samples were later subjected to ELISA test kit for confirmation, and quantification for presence of oxytetracycline residues.

Screening of antimicrobial residues obtained from the tissue samples of Bunaji cattle slaughtered in the study area

The results for the screening to test for antimicrobial residues in the samples is shown in Table 1. Out of 168 samples analyzed for antimicrobial residues during this study; $89(52.97 \%)$ comprising of 29 $(17.26 \%)$ meat, $37(22.02 \%)$ liver and 23(13.69\%) kidney samples were positive at different inhibition zones ranging- from 13 to $20 \mathrm{~mm}$ while the remaining $79(47.03 \%)$ were negative for anti microbial residues. obtained for meat, liver and kidney, respectively, while female animals had the highest value of $63(70.78 \%)$, comprising, $20(68.96 \%), 29(78.37 \%)$ and $14(60.36 \%)$ for meat, liver and kidney, respectively. On age variation of the positive samples, 6-10 years had the highest value of 56(62.92\%), $0-5$ years $21(23.59 \%)$ and above 10 years with $12(13.48 \%)$. 
Detection of antimicrobial drug residues in edible tissues from Bunaji cattle

Table 2: Distribution of antimicrobial residues obtained from tissue samples of Bunaji slaughtered in the study area based on sex and age

\begin{tabular}{llccccc}
\hline Samples & \multicolumn{2}{c}{ Sex } & \multicolumn{2}{c}{ Age } & \multirow{2}{*}{ Total } \\
\cline { 2 - 6 } & Males (\%) & Females & $\mathbf{0 - 5}(\mathbf{\%})$ & $\mathbf{6 - 1 0 ( \% )}$ & $>\mathbf{1 0}(\mathbf{\%})$ & \\
\hline MEAT & $9(31.03)$ & $20(68.96)$ & $7(24.13)$ & $17(58.62)$ & $5(17.24)$ & 29 \\
LIVER & $8(25.80)$ & $29(78.37)$ & $9(24.32)$ & $24(64.86)$ & $4(10.81)$ & 37 \\
KIDNEY & $9(39.13)$ & $14(60.86)$ & $5(21.73)$ & $15(65.21)$ & $3(13.04)$ & 23 \\
TOTAL & $\mathbf{2 6 ( 2 9 . 2 1 )}$ & $\mathbf{6 3 ( 7 0 . 7 8 )}$ & $\mathbf{2 1 ( 2 3 . 5 9 )}$ & $\mathbf{5 6}(\mathbf{6 2 . 9 2})$ & $\mathbf{1 2}(\mathbf{1 3 . 4 8 )}$ & $\mathbf{8 9}$ \\
\hline
\end{tabular}

The results of ELISA test kit for confirmatory and quantifications of Oxytetracycline residues

The results of ELISA test kit for confirmatory and quantifications of Oxytetracycline residues is illustrated in Table 3. Out of the 89 tissue samples positive for antimicrobial residues, Oxytetrocycline residues was detected on all the samples $(100 \%)$ by the Elisa kit. $37(41.57 \%)$ were above the set residue limit, with $25(86.20 \%), 10(32.25 \%)$ and $2(8.69 \%)$ for meat, liver and kidney, respectively.

Table 3: Quantification of OTC residues obtained from the tissue samples using ELISA test kit

\begin{tabular}{llllll}
\hline Samples & MRL & \multicolumn{3}{c}{ Range of residues result (\%) } & Mean LS \\
\cline { 3 - 5 } & & Below limit & Within limit & Above limit & \\
\hline Meat & $0.2 \mathrm{mg} / \mathrm{kg}$ & $1(3.44 \%)$ & $3(10.34 \%)$ & $25(86.20 \%)$ & $0.4122 \mathrm{NS}$ \\
Liver & $0.6 \mathrm{mg} / \mathrm{kg}$ & $27(72.97 \%)$ & 0 & $10(32.25 \%)$ & $0.2830 \mathrm{NS}$ \\
Kidney & $1.2 \mathrm{mg} / \mathrm{kg}$ & $21(91.31 . \%)$ & 0 & $2(8.69 \%)$ & $0.2248 \mathrm{NS}$ \\
Total & & $\mathbf{4 9 ( 5 5 . 0 5 \% )}$ & $\mathbf{3 ( 3 . 3 7 )}$ & $\mathbf{3 7 ( 4 1 . 5 7 \% )}$ & \\
\hline
\end{tabular}

OTC:-oxytetracycline; MRL:-maximum residue limit.

Mean value not significant $(\mathrm{p}>0.05)$

Distribution of oxtetracycline residues based on sex of the animals

Results of oxytetracycline residues based on the sex of the animals is shown in Table 4. The result of oxytetracycline residues based on sex showed female animals had the highest residue values of $29(32.98 \%)$ for total samples and $20(68.96), 8(21.62 \%)$ and $1(4.34 \%)$ for meat, liver and kidney respectively; Males had $8(8.99 \%)$ of the total samples, which comprises, Meat 5 (17.24), liver $2(5.40 \%)$ and kidney 1 (4.34\%).

Table 4: Distribution of OTC residues obtained from tissue samples of Bunaji cattle based on sex of the animals

\begin{tabular}{lllllll}
\hline \multirow{2}{*}{ SAMPLE } & \multirow{2}{*}{ MRL } & \multicolumn{2}{l}{ BELOW MRL } & \multicolumn{2}{l}{ ABOVE MRL } & TOTAL \\
\cline { 3 - 5 } & & Male & Female & Male & Female & \\
\hline MEAT & $0.2 \mathrm{mg} / \mathrm{kg}$ & $2(6.89 \%)$ & $2(6.89 \%)$ & $5(17.24)$ & $20(68.96 \%)$ & 29 \\
LIVER & $0.6 \mathrm{mg} / \mathrm{kg}$ & $5(13.52 \%)$ & $22(59.45 \%)$ & $2(5.40 \%)$ & $8(21.62 \%)$ & 37 \\
KIDNEY & $1.2 \mathrm{mg} / \mathrm{kg}$ & $4(17.39)$ & $17(73.91)$ & $1(4.34)$ & $1(4.34 \%)$ & 23 \\
TOTAL & & $\mathbf{1 1}(\mathbf{1 2 . 3 5 \% )}$ & $\mathbf{4 1 ( 4 6 . 0 6 \% )}$ & $\mathbf{8 ( 8 . 9 9 \% )}$ & $\mathbf{2 9 ( 3 2 . 9 8 \% )}$ & $\mathbf{8 9}$ \\
\hline
\end{tabular}

Distribution of oxytetracycline residue based on age of the animals

Results for distribution of oxytetracycline residue based on age of animals is shown in table 5. Oxytetracycline residues above set limit confirmed within age groups showed, $11(12.36 \%) ; 22(24.71 \%)$ and $4(4.41 \%)$ as values obtained for ages $0-5$; 6-10 and above 10 years respectively. 
Table 5: Distribution of Oxytetracycline residues obtained from tissue sample s of Bunaji cattle based on age

\begin{tabular}{lllllllll}
\hline Samples & \multirow{2}{*}{ MRL } & $\begin{array}{r}\text { OTC } \\
\text { Below } /-\end{array}$ & \multicolumn{2}{c}{ Residues } & \multicolumn{5}{c}{ Total } \\
& & & \multicolumn{7}{c}{ Above residue } & \\
\hline & & $0-5$ & $6-10$ & $>10$ & $0-5$ & $6-10$ & $>10$ \\
MEAT & $0.2 \mathrm{mg} / \mathrm{kg}$ & $1(3.44)$ & $2(6.89)$ & $1(3.44)$ & $6(20.69)$ & $16(55.17)$ & $3(10.34)$ & 29 \\
LIVER & $0.6 \mathrm{mg} / \mathrm{kg}$ & $6(16.21)$ & $16(43.24)$ & $5(13.51)$ & $3(8.11)$ & $6(16.21)$ & $1(2.70)$ & 37 \\
KIDNEY & $1.2 \mathrm{mg} / \mathrm{kg}$ & $3(13.04)$ & $15(65.21)$ & $3(13.04)$ & $2(8.67)$ & 0 & 0 & 23 \\
TOTAL & & $10(11.23$ & $33(37.01)$ & $9(10.11)$ & $11(12.36)$ & $22(24.71)$ & $4(4.41)$ & 89 \\
\hline
\end{tabular}

\section{Discussion}

The overall results from this study when considered regardless of the tissue types, indicated high incidence of $89(52.97 \%)$ for antimicrobial drug residues and $37(41.5 \%)$ above set residue limit for oxytetracycline (Prajapast et al., 2018). The high occurrences of antimicrobial residues found in this study on meat, liver and kidney have been reported by several authors; $89.3 \%$ from kidney and urine (Gabriel et al., 2012); 69. $74 \%$ in edible tissues (Olaloye and Ogundipe, 2009). However, the result is higher than $46 \%$ in beef in Oyo (Akinwumi, 2012); 16.11\% (Dipeolu and alonge, 2002) and 25\% in milk (Yusuf et al., 2017). The outcome from this study found $41.57 \%$ of the samples to have oxytetracycline maximum residue value, the result however agreed with that reported by Omotoso and Omojola (2018) but lower than $71.1 \%$ in Cattle beef in Tanzania (kamirosa et al., 2005); 71.3\% from cattle in Ethiopia (Zeroda, 2012); $54.4 \%$ in muscle samples reported in studies from Kenya (Muruiki et al., 2001), respectively. The occurrence of antimicrobial residues and Oxtertracycline residues above set limit showed that, females had the highest residue of $70.78 \%$ and $32.98 \%$ for antimicrobial and Oxytetracycline residues respectively. This could be attributed to indiscriminate administration of drugs during pregnancy at a time that they probably have compromised immune system. $62.92 \%$ of antimicrobial residues and $24.71 \%$
Oxytetracycline residues were obtained above based on age variation between 6-10 years, the result is higher than $14.7 \%$ reported by Zeenatudeen, (2015) on raw cow milk. High levels of antimicrobial and Oxytetracycline residues was found in liver and meat which could be attributed to their being responsible for absorption and metabolism of drugs. Marketers, herdsmen and butchers all administered veterinary drugs indiscriminately, with Oxytetracycline long acting drugs which had slow absorption rate.

The high prevalence of $41.57 \%$ of Oxytetracycline residues obtained from the study using Elisa test kit by quantification is an indication of wide spread misuse of Veterinary drugs for therapeutic, prophylactic and as growth promoters by food animal producers in the study area. Veterinary drugs are easily accessible over the counter and in rural cattle Markets in Nigeria without prescription by veterinary personnel. Most times these animals are treated in the butcher's house or lairage, where antimicrobial inspection is not fully employed before slaughter. The indiscriminate use of antimicrobial substances and non observance of withdrawal period has been reported as the major cause of violative residues in animal food products (Riviere and soundlof, 2001) which had also led to availability of unsafe meat to consumers. Olatoye and Ehinmowo (2014) reported drugs resides due to indiscriminate and wide spread misuse of veterinary drugs which could be attributed 
to the fact that greater proportions of cattle rearing in Nigeria is mostly by nomadic herdsmen.

The presence of drug residues in animal products portends great risk and hazard to human health that could result in Allergy, kidney disease, toxicity and drug resistance (Alhendi, 2000).

\section{Conclusion}

The high percentage of meat with antimicrobial residues obtained from this study indicates that, consumers in Minna metropolitan are predisposed to health hazards due to the presence of antimicrobial residues in meat in slaughtered animals from the abattoir, this emphasises the need for the enforcement of antimortem inspection, effective prevention of infectious diseases, general enlightenment on drug withdrawal periods, and possible establishment of antimicrobial residues monitoring unit in Minna modern abattoir.

\section{Acknowledgement}

Special appreciation goes to Africa centre of excellence on mycotoxin and food safety(ACEMFS), Federal University of Technology, Minna for all the support and collaboration on this work.

References

Akinwumi, A. O., Adunsi, A. A., Ojola, A. B and Rafiu, T. A. 2012. Effect of Antibiotic Residue on the physical qualities of Beef in Oyo State Nigeria. $4^{\text {th }}$ International Conference on Agriculture and Animal Science. DOI: 10.7763/IPCBEE. V47-15

Alhendi, A. B. 2000. drug residue in broiler chicken fed with antibiotic in ration; Veterinarski Archive 70(4) 199-205

Davis, J. L., Salmon, J. H. and Papich, M. G. 2006. Pharmacokinetics and tissue distribution of doxycycline after oral administration of single and multiple doses in horses.
American Journal Veterinary Resources. 67, 310-316. (CrossRef)(PubMed)

Dipeolu, M. A. and Alonge, D. O. 2002. Residues of streptomycin antibiotic in meat sold for human consumption in some states of south-western Nigeria. Arch. Zootec. 51, 477-480.

Donoghue, D. J. 2003. Antibiotic residues in poultry tissues and eggs: Human health concerns. Yozrlt. Sci., 82: 618-621.

Gabriel, K. O., Ajayi, I. E and Ode, O. J. 2012. Assessment of antimicrobial drugs residue in beef in Abuja Federal Capital Territory, Nigeria, Veterinaria italiana,48(3) 283-289.

Huber, W. G., Caslon T. M. B. and Lepper, M. H. 1969. Pennicillin and antibiotic residues in domestic animals at slaughter. Food microbiology, 154; 1590-1595

Kamirosa, E. D., Mdegela, R. H., Kusiluka, L. J . M and Ka mbarage, D. M. 2005. Assessment of antimicrobial usage and antimicrobial residues in milk on small holder farms in Morogoro, Tanzania Bulletin of Animal Health and Production in Africa, 53: 234241.

Karbis, A. 2007. Microbiological screening method for Detection of aminoglycosides, B- lactomas, macidider, tetracyclines and quinolones in meat samples. Veterinary Resources. 44(2): 11-48.

Kozarova, L., Mate, D. and Cabadaj, R. 2001 . Methods for the determination of sulphonamides residues in milk and animal $\mathrm{n}$ products In: Proceeding of Lectures and Posters of the Imternational Conference, Hygiena Alimentorium XXIII.

Muriuki, F.K., Ogara, W.O., Njeruh and 
Mitema, E. S. 2001. Tetracycline residue levels in cattle meat from Nairobi slaughterhouse in Kenya. Journal of veterinary sciences, 2, 97 $-101$

Niger State Fadama Coordition Office ( N S F C O ) / A g ricultura l Development Project (ADP) Minna (2015). Annual report.

Olatoye I. O, and A.A. Ehinmowo. 2014. Oxytetracycline residue in edible tissues of cattle slaughtered in Akure, Nigeria.International Journal of food safety, 11:62-66.

Omotoso, A. B., and Omojola, A. 2018. Fluoroquinolone residues in raw meat from open markets in Ibadan, Southwest, Nigeria. International Journal of Health and Animal Science Food Safety, 2(1): 32-40. doi: 10.13130/2283-3927/4739.

Olatoye, O. I and Ogundipe, T. 2009. Preliminary screening of beef consumed in Ibadan Nigeria for antimicrobial residue. Africa journal of biomedical research vol. 12 , no.3,

Prajapaty, M, Ranjat, E, Shrestha, R and Shretha, S. P. 2018. Status of antibiotic residues in poultry meat Nepal. Nepal Veterinary Journal. 35: 55-62.
Riviere J.E and Sundlof S.F. 2001. Chemical residue in tissues of food animals. In: Veterinary Pharmacological Therapeutics. Ed. Adams HR: 8th Edition; Blackwell Publishing Professional Lowa pp.1166-1174.

Shehu .2018. How antibiotics in livestock farming places all at risk, Daily trust Newspaper, published December 27, 3:26 am.

SPSS. 2010. Statistical Package for the Social sciences, Version 16.0 IBM USA.

Wasengula, A. 2018. Punch Newspaper, $9^{\text {th }}$ November, 2018.

Yusuf, M. S., Kabir, J. And Babashani, M. 2017. Occurrence of Tetracycline Residue in Milk from Diary Farms in Kano state Nigeria. Proceedings of $54^{\text {th }}$ Annual Congress of the Nigerian Veterinary Medical Association, Pg 145-147.

Zeenatudeen, M. 2015. Dissertation submitted to the postgraduate school Department of Veterinary Public Health and Preventive Medicine, Ahmadu Bello University Zaria.

Received: $21^{1 \text { st }}$ June, 2020

Accepted: $19^{\text {th }}$ December, 2020 